\title{
The safety of moderate hypothermic lower body circulatory arrest with selective cerebral perfusion: A propensity score analysis
}

Hiroyuki Kamiya, MD, Christian Hagl, MD, Irina Kropivnitskaya, Dietmar Böthig, MD, Klaus Kallenbach, MD, Nawid Khaladj, MD, Andreas Martens, MD, Axel Haverich, MD, and Matthias Karck, MD

Supplemental material is available online.
From the Division of Thoracic and Cardiovascular Surgery, Hannover Medical School, Hannover, Germany.

Received for publication Feb 14, 2006; revisions received July 20, 2006; accepted for publication Sept 5, 2006.

Address for reprints: Hiroyuki Kamiya, MD, Department of Cardiac Surgery, University of Heidelberg, INF 110, 69120 Heidelberg, Germany, (E-mail: Hiroyuki.Kamiya@ med.uni-heidelberg.de).

J Thorac Cardiovasc Surg 2007;133:501-9

$0022-5223 / \$ 32.00$

Copyright $\odot 2007$ by The American Association for Thoracic Surgery

doi:10.1016/j.jtcvs.2006.09.045
Objective: There is no common guideline on what temperature should be achieved at the lower body circulatory arrest followed by the initiation of selective cerebral perfusion.

Methods: Between October 1999 and August 2005, a total of 377 patients underwent repair of the aortic arch with selective cerebral perfusion and hypothermic circulatory arrest at $20^{\circ} \mathrm{C}$ to $28^{\circ} \mathrm{C}$ and were divided into two groups: (1) 125 patients with deep lower body circulatory arrest at $20^{\circ} \mathrm{C}$ to $24.9^{\circ} \mathrm{C}$ (deep lower body circulatory arrest group) and (2) 252 patients with moderate lower body circulatory arrest at $25^{\circ} \mathrm{C}$ to $28^{\circ} \mathrm{C}$ (moderate lower body circulatory arrest group). To compensate for the differences in patient characteristics, we used a propensity score matching analysis, and comparable patients, 92 patients from each group, were identified for final analysis.

Results: There were no significant differences in mortality or morbidity between deep and moderate lower body circulatory arrest, in either the entire study cohort or the propensity-matched cohort. C-reactive protein level 1 day after the operation approached but fell short of significance $(108.4 \pm 47.7 \mathrm{mg} / \mathrm{L}$ in deep lower body circulatory arrest group and $95.8 \pm 44.2 \mathrm{mg} / \mathrm{L}$ in moderate lower body circulatory arrest group, $P=.07)$. The mean temperatures at the initiation of lower body circulatory arrest were $24.1^{\circ} \mathrm{C} \pm 2.2^{\circ} \mathrm{C}$ in patients who underwent reexploration for bleeding and $24.9^{\circ} \mathrm{C} \pm 1.8^{\circ} \mathrm{C}$ in patients who did not $(P=.025)$; the difference also reached statistical significance in multivariate analysis $(P=.046$, odds ratio 0.796$)$.

Conclusions: Our results suggest that moderate lower body circulatory arrest can be safely performed for aortic arch repair. In fact, postoperative inflammatory response tended to be lower in patients with moderate lower body circulatory arrest than those with deep lower body circulatory arrest, and deep lower body circulatory arrest was a strong risk factor for reexploration for bleeding.

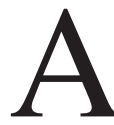
lthough the introduction of deep hypothermic circulatory arrest (HCA) improved surgical results of more extensive operations on the thoracic aorta, ${ }^{1,2}$ these complex procedures are still associated with a relatively high mortality and high incidences of neurologic complications. As is well known, the safe duration of HCA alone is limited, ${ }^{3-6}$ and HCA is therefore normally performed with the use of retrograde cerebral perfusion or antegrade selective cerebral perfusion (SCP). Because the real benefit of retrograde cerebral perfusion is not uniformly accepted, ${ }^{6,7}$ the combination of HCA and SCP is currently adopted in many institutions. There is no common guideline as to the temperature that should be achieved before extracorporeal circulation can be stopped and followed by the initiation of SCP, however, and each institution has its own protocol. 


\section{Abbreviations and Acronyms \\ $\mathrm{CPB}=$ cardiopulmonary bypass \\ $\mathrm{HCA}=$ hypothermic circulatory arrest \\ LBCA $=$ lower body circulatory arrest \\ SCP $=$ selective cerebral perfusion}

Until now, discussions regarding HCA have been focused on cerebral protection and neurologic outcome. Originally, deep HCA was introduced as a method of cerebral protection, and because the brain is the most sensitive organ to ischemic injury, it is considered that the temperature should be dropped to $20^{\circ} \mathrm{C}$ or lower when no other adjunct cerebral protection is available. With the use of SCP, however, HCA acts as lower body circulatory arrest (LBCA), and the temperature for HCA can therefore be higher. To distinguish between HCA of the entire body and HCA of the lower body, HCA with the use of SCP is defined as LBCA in this article.

In recent years, the trend has gone from deep temperatures, cooler than $20^{\circ} \mathrm{C}$ as advocated by the Mount Sinai group, ${ }^{6}$ toward temperatures as high as $25^{\circ} \mathrm{C}^{8-10}$ The avoidance of deep core temperatures at LBCA may offer the advantage of shorter cardiopulmonary bypass (CPB) times and reductions in coagulation disorders and the accumulation of inflammatory parameters, but it can theoretically cause ischemic injury to the visceral organs and the spinal cord.

In our institution, SCP was introduced in 1999 in combination with deep HCA at temperatures lower than $20^{\circ} \mathrm{C}$. The temperature of LBCA has gone higher as we gained experience, and it is now performed at $25^{\circ} \mathrm{C}$ to $28^{\circ} \mathrm{C}$. This temperature is clearly higher than in other institutions, where it is performed at $20^{\circ}$ to $25^{\circ} \mathrm{C}^{8-10}$ It is difficult to say whether the results are acceptable, however, because previous studies had no control group regarding the temperature of LBCA. The aim of this study was to compare the inhospital outcomes of patients with LBCA at $25^{\circ} \mathrm{C}$ to $28^{\circ} \mathrm{C}$ with those of a propensity-matched group of patients with LBCA at $20^{\circ} \mathrm{C}$ to $24.9^{\circ} \mathrm{C}$.

\section{Patients and Methods Patients}

Between October 1999 and August 2005, a total of 832 adult patients underwent surgery for ascending aortic disease through a median sternotomy with or without a repair of the aortic arch, and LBCA (HCA with SCP) was used in 473 cases. Among these patients, 60 who were operated on with the use of profound LBCA at a nasopharyngeal temperature lower than $20^{\circ} \mathrm{C}$ and 36 operated on with the use of moderate LBCA at a nasopharyngeal temperature higher than $28^{\circ} \mathrm{C}$ were excluded; the remaining 377 patients were retrospectively examined in this study. These 377 patients were divided into two groups according to nasopharyngeal tem- perature at the initiation of HCA: (1) 125 patients (33.1\%) underwent deep LBCA at a nasopharyngeal temperature of $20^{\circ} \mathrm{C}$ to $24.9^{\circ} \mathrm{C}$ (deep LBCA group) and (2) 252 patients (66.9\%) underwent moderate LBCA at a nasopharyngeal temperature of $25^{\circ} \mathrm{C}$ to $28^{\circ} \mathrm{C}$ (moderate LBCA group). All patient characteristics were assessed and are presented in Table 1. The distribution of patients according to HCA time is shown in Figure 1.

\section{Operative Technique}

Anesthesia was induced and maintained in a standard manner. The proximal thoracic aorta was approached through a median sternotomy in all cases. After systemic heparinization, CPB was instituted with a cannula for arterial return to the aortic arch, even in cases of acute aortic dissection type $\mathrm{A},{ }^{10}$ and a venous single two-stage cannula in the right atrium. The left side of the heart was vented through the right superior pulmonary vein. Myocardial protection was achieved with cold blood cardioplegia. The ascending aorta was clamped, and manipulation of the proximal site was performed. After the patient was cooled to the target temperature, the systemic circulation was arrested, the aneurysm was opened, and the arterial cannula was removed. With the patient in the Trendelenburg position, $15 \mathrm{~F}$ retrograde coronary sinus perfusion cannulas (Medtronic DLP, Grand Rapids, Mich) connected to the oxygenator with a separate single-roller pump head were inserted into the innominate artery and the left carotid artery. The left subclavian artery was clamped or occluded with a Fogarty catheter (Baxter Healthcare Corporation, Deerfield, Ill) to avoid the steal phenomenon. For SCP, cold blood at $15^{\circ} \mathrm{C}$ was perfused with a circuit for blood cardioplegia. Cerebral perfusion was initiated at a rate of $10 \mathrm{ml} /(\mathrm{min} \cdot \mathrm{kg})$ and adjusted to maintain a pressure between 40 and $60 \mathrm{~mm} \mathrm{Hg}$. After the aortic arch was repaired, SCP was ceased and $\mathrm{CPB}$ was resumed with the perfusion cannula directly reinserted into the graft. Deairing was performed in a standard manner.

\section{Definitions of Complications}

In accordance with the report by Ergin and colleagues, ${ }^{5}$ we defined temporary neurologic dysfunction as the occurrence of at least one of the following symptoms: postoperative confusion, agitation, delirium, prolonged obtundation, or transient parkinsonism without obvious neurologic deficit. Stroke was defined as the presence of transient or permanent focal neurologic deficit that was confirmed as a new deficit by means of computed tomography. Respiratory insufficiency was defined as prolonged intubation for more than 48 hours because of inadequate status of gas exchange. Criteria for extubation included adequate response to commands, respiratory rate greater than 12 breaths/min, end-tidal carbon dioxide tension less than $50 \mathrm{~mm} \mathrm{Hg}$, and an oxygen saturation by pulse oximetry greater than $95 \%$ at an inspired oxygen fraction of 0.3 .

\section{Statistical Analysis}

Results are expressed as mean \pm SD. Statistical analyses were performed with the Student $t$-test for continuous variables or with $\chi^{2}$ tests (Fisher exact tests if $\mathrm{n}<5$ ) for categorical variables.

In view of the marked and significant differences in patient characteristics between the groups, patient matching seemed necessary to evaluate the genuine effects of temperature on mortality and morbidity. To compensate for the differences in this retrospec- 


\begin{tabular}{|c|c|c|c|c|c|c|c|c|}
\hline & \multicolumn{4}{|c|}{ Entire study sample } & \multicolumn{4}{|c|}{ Propensity-matched pairs } \\
\hline & Overall & $\begin{array}{l}\text { Deep } \\
\text { LBCA }\end{array}$ & $\begin{array}{l}\text { Moderate } \\
\text { LBCA }\end{array}$ & $P$ value & Overall & $\begin{array}{l}\text { Deep } \\
\text { LBCA }\end{array}$ & $\begin{array}{l}\text { Moderate } \\
\text { LBCA }\end{array}$ & $P$ value \\
\hline Patients (No.) & 377 & 125 & 252 & & 184 & 92 & 92 & \\
\hline Age $(y$, mean $\pm S D)$ & $61.8 \pm 11.8$ & $60.9 \pm 13.1$ & $62.3 \pm 11.1$ & .31 & $62.1 \pm 11.2$ & $62.2 \pm 12.0$ & $62.0 \pm 10.0$ & .88 \\
\hline Male (No.) & $262(69.5 \%)$ & $81(64.8 \%)$ & $181(71.8 \%)$ & .16 & $123(66.8 \%)$ & $60(65.2 \%)$ & $63(68.4 \%)$ & .63 \\
\hline Body mass index $\left(\mathrm{kg} / \mathrm{m}^{2}\right.$, mean $\left.\pm \mathrm{SD}\right)$ & $26.5 \pm 4.1$ & $25.6 \pm 3.8$ & $27.0 \pm 4.2$ & .002 & $26.3 \pm 3.6$ & $26.2 \pm 3.8$ & $26.4 \pm 3.4$ & .79 \\
\hline Reoperative case (No.) & $72(19.1 \%)$ & $24(19.2 \%)$ & $48(19.0 \%)$ & .97 & $33(17.9 \%)$ & $17(18.4 \%)$ & $16(17.3 \%)$ & .84 \\
\hline Emergency (No.) & $141(37.4 \%)$ & $55(44.0 \%)$ & $86(34.1 \%)$ & .62 & $71(38.6 \%)$ & $37(40.2 \%)$ & $34(36.9 \%)$ & .65 \\
\hline Type A dissection (No.) & $126(33.4 \%)$ & $50(40.0 \%)$ & $76(30.1 \%)$ & .57 & $66(35.9 \%)$ & $34(36.9 \%)$ & $32(34.7 \%)$ & .75 \\
\hline Marfan syndrome (No.) & $7(1.9 \%)$ & $6(4.8 \%)$ & $1(0.3 \%)$ & .003 & $1(0.5 \%)$ & $0(0 \%)$ & $1(1.08 \%)$ & .31 \\
\hline \multicolumn{9}{|l|}{ History of neurologic event (No.) } \\
\hline Transient & $11(2.9 \%)$ & $6(4.8 \%)$ & $5(1.9 \%)$ & .12 & $4(2.2 \%)$ & $1(1.08 \%)$ & $3(3.2 \%)$ & .31 \\
\hline Persistent & $25(6.6 \%)$ & $7(5.6 \%)$ & $18(7.1 \%)$ & .57 & $14(7.6 \%)$ & $7(7.6 \%)$ & $7(7.6 \%)$ & $>.99$ \\
\hline Smoking history (No.) & $133(35.3 \%)$ & $56(44.8 \%)$ & $77(30.5 \%)$ & .006 & $82(44.6 \%)$ & $42(45.6 \%)$ & $40(43.4 \%)$ & .76 \\
\hline Hypertension (No.) & $291(77.2 \%)$ & $99(79.2 \%)$ & $192(76.1 \%)$ & .51 & $148(80.4 \%)$ & $74(80.4 \%)$ & $74(80.4 \%)$ & $>.99$ \\
\hline $\begin{array}{l}\text { Hyperlipidemia (cholesterol }>200 \\
\text { mg/dL, No.) }\end{array}$ & $168(44.6 \%)$ & $55(44.0 \%)$ & $113(44.8 \%)$ & .87 & $84(45.7 \%)$ & $41(44.5 \%)$ & $43(46.7 \%)$ & .76 \\
\hline $\begin{array}{l}\text { Diabetes mellitus (insulin dependent, } \\
\text { No.) }\end{array}$ & $4(1.1 \%)$ & $1(0.8 \%)$ & $3(1.1 \%)$ & .72 & $2(1.1 \%)$ & $1(2.3 \%)$ & $1(2.3 \%)$ & $>.99$ \\
\hline $\begin{array}{l}\text { Chronic obstructive pulmonary } \\
\text { disease (No.) }\end{array}$ & $79(21.0 \%)$ & $28(22.4 \%)$ & $51(20.2 \%)$ & .62 & $43(23.4 \%)$ & $22(23.9 \%)$ & $21(22.8 \%)$ & .86 \\
\hline Peripheral arterial disease (No.) & $12(3.2 \%)$ & $4(3.2 \%)$ & $8(3.1 \%)$ & .98 & $9(4.9 \%)$ & $4(4.3 \%)$ & $5(5.4 \%)$ & .73 \\
\hline Coronary artery disease (No.) & $113(30.0 \%)$ & $29(23.2 \%)$ & $84(33.3 \%)$ & .43 & $55(29.9 \%)$ & $25(27.1 \%)$ & $30(32.6 \%)$ & .42 \\
\hline Chronic renal insufficiency (No.) & $40(10.6 \%)$ & $11(8.8 \%)$ & $29(11.5 \%)$ & .42 & $15(8.2 \%)$ & $8(8.6 \%)$ & $7(7.6 \%)$ & .78 \\
\hline
\end{tabular}

LCBA, Lower body circulatory arrest.

tive, nonrandomized study, we used a propensity score matching analysis. For this purpose, logistic regression was used to develop a propensity score. ${ }^{11,12}$ The propensity score included age, sex, body mass index, reoperation, emergency operation, Marfan syndrome, previous neurologic events, smoking history, hypertension, hyperlipidemia, chronic obstructive pulmonary disease, diabetes

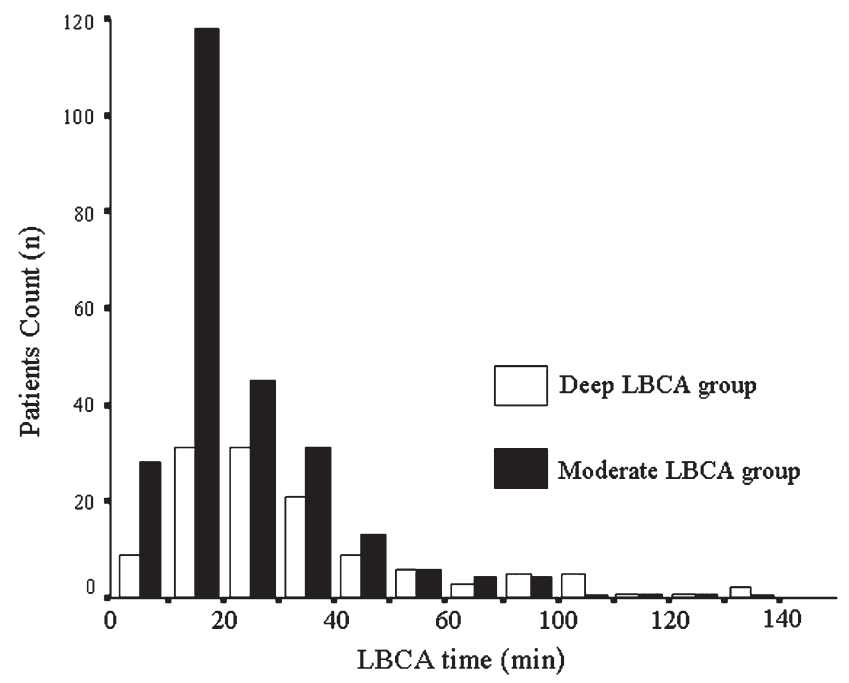

Figure 1. Distribution of patients by hypothermic circulatory arrest time. $L B C A$, Lower body circulatory arrest. mellitus (insulin dependent), peripheral vascular disease, coronary artery disease, renal insufficiency (creatinine $>2.0 \mathrm{mg} / \mathrm{dL}$ ), total arch replacement, concomitant operations (aortic valve root operation, coronary artery bypass grafting, mitral valve operation), duration of aortic crossclamping, and duration of LBCA. From these covariables, a propensity score was calculated for each patient. Finally, each patient in the deep LBCA group was matched with a patient in the moderate LBCA group with the closest propensity score. The maximum difference in propensity score for a match was less than 0.015. By using this novel method, comparable patient groups (92 patients from each group) were identified for final analysis (Table 1). Logistic regression was also used for the analysis of risk factors for postoperative mortality and morbidity and the effects of temperature on postoperative mortality and morbidity. All statistical analyses were performed with SPSS 10.0 software (SPSS Inc, Chicago, Ill).

\section{Results}

\section{Analysis of the Entire Patient Population}

Rate of total arch replacement was significantly higher in the deep LBCA group than in the moderate LBCA group (31\% vs $19 \%, P=.008)$. This may be related to longer durations of LBCA $(34.1 \pm 24.4$ minutes in deep LBCA group vs $23.5 \pm$ 15.8 minutes in moderate LBCA group, $P=.001)$, SCP $(25.8 \pm 18.1$ vs $18.8 \pm 14.2$ minutes, $P=.001), \mathrm{CPB}$ $(193.3 \pm 77.9$ vs $175.7 \pm 67.1$ minutes, $P=.025)$, and operation $(304.8 \pm 112.5$ vs $279.2 \pm 92.6$ minutes, $P=$ 
TABLE 2. Perfusion data and postoperative morbidity and mortality

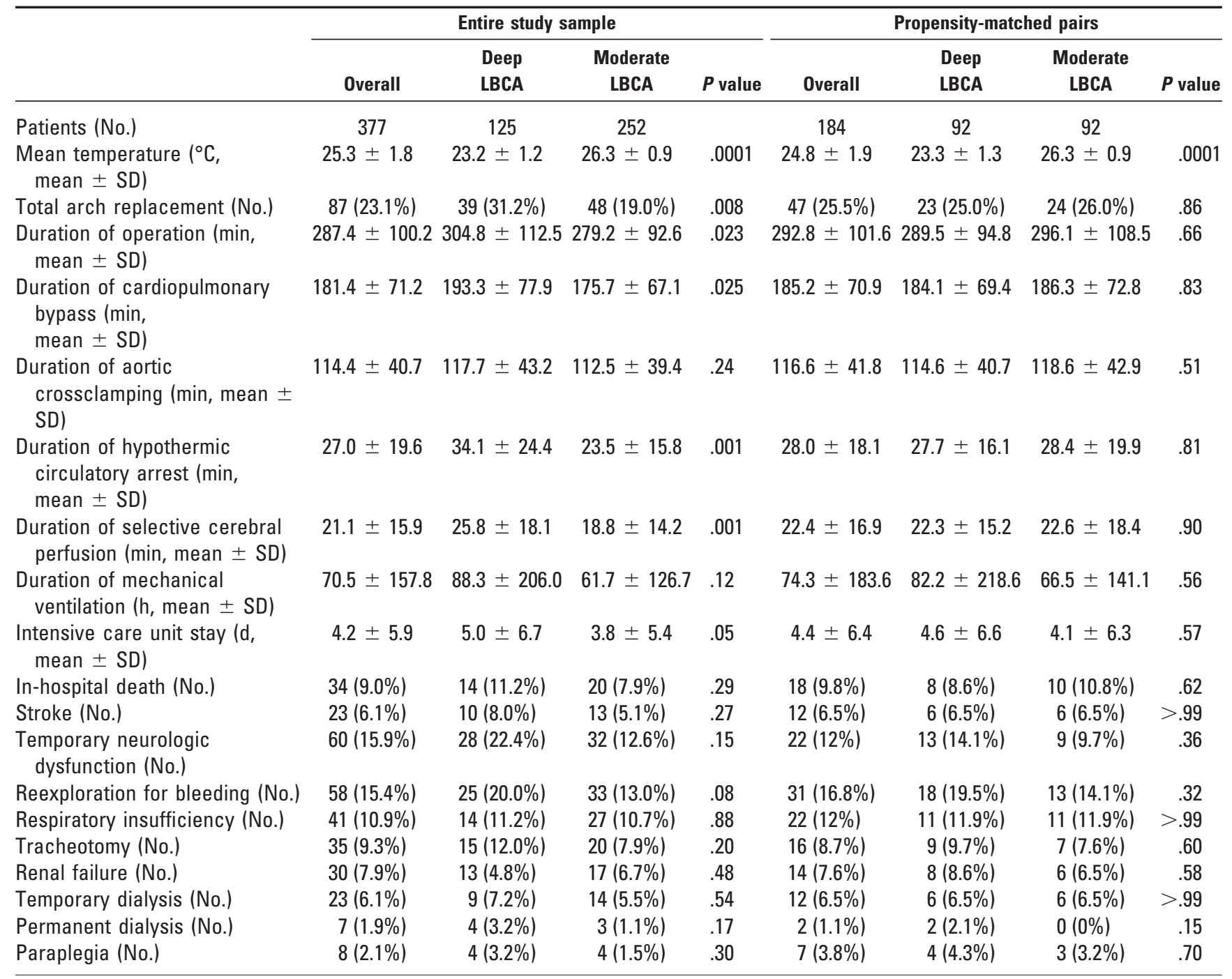

.023) in the deep LBCA group than in the moderate LBCA group. Intensive care unit stay was longer in the deep LBCA group $(5.0 \pm 6.7$ vs $3.8 \pm 5.4$ days, $P=.05)$. In-hospital mortalities were $11.2 \%$ in the deep LBCA group and $7.9 \%$ in the moderate LBCA group $(P=.29)$. There was a trend toward a higher rate of reexploration for postoperative bleeding in the deep LBCA group ( $20 \%$ vs $13 \%, P=.08$ ); however, there were no differences in other complications between the groups (Table 2).

\section{Propensity Score Matching Analysis}

Baseline characteristics of propensity-matched pairs were almost identical (Table 1). There were no significant differences in CPB time (184.1 \pm 69.4 in deep LBCA group vs $186.3 \pm 72.8$ minutes in moderate LBCA group, $P=.83$ ) and operative time $(289.5 \pm 94.8$ vs $296.1 \pm 108.5$ minutes, $P=.62$ ) between the deep and moderate LBCA groups.
In-hospital mortalities were $8.6 \%$ in the deep LBCA group and $10.8 \%$ in the moderate LBCA group $(P=.62)$. There was no significant difference in reexploration for postoperative bleeding between the deep and moderate LBCA groups (19.5\% vs $14.1 \%, P=.32$ ) and also no differences in any other postoperative complications between the groups (Table 2).

Time courses of the following factors were also analyzed in the propensity-matched groups: blood urea nitrogen, creatinine, and urinary output as an index of renal function; aspartate aminotransferase as an index of liver injury; creatine kinase as an index of muscle injury; lactate as an index of whole-body ischemic injury; C-reactive protein as an index of inflammatory response; and ratio of arterial to inspired oxygen concentration as an index of gas exchange function (Appendix Table E1). Only the difference in C-reactive protein 


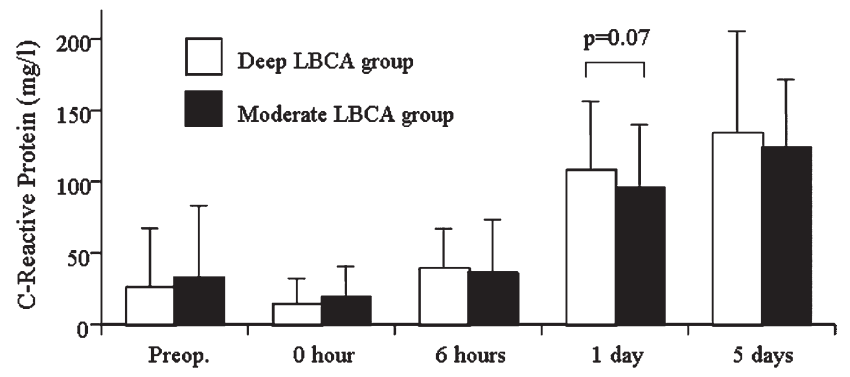

Figure 2. Time course of C-reactive protein in propensitymatched groups. LBCA, Lower body circulatory arrest; Preop., preoperative.

level at 1 day after the operation approached (but did not reach) statistical significance $(108.4 \pm 47.7 \mathrm{mg} / \mathrm{L}$ in deep LBCA group vs $95.8 \pm 44.2 \mathrm{mg} / \mathrm{L}$ in moderate LBCA group, $P=$ .07 ; Figure 2).

\section{Subanalysis 1: Patients With LBCA Longer Than 60 Minutes}

As shown in Figure 1, most of the patients underwent LBCA for less than 60 minutes, and only 27 (7\%) patients underwent LBCA for longer than 60 minutes. Prolonged LBCA can theoretically lead to higher mortality, and prolonged LBCA at higher temperature appears to be dangerous; an additional subanalysis was therefore performed on the entire patient population to examine any effects of the temperature at the initiation of LBCA on the outcomes of patients with LBCA duration longer than 60 minutes. Mortalities were 19\% (5/27 patients) among patients who underwent LBCA for longer than 60 minutes and 8\% (29/350 patients) among those with LBCA less than 60 minutes $(P=.08)$. Among the 27 patients with LBCA longer than 60 minutes, mortalities were $12.5 \%$ in the deep LBCA group and $27.3 \%$ in the moderate LBCA group $(P=.33)$. There was a trend toward higher occurrence of paraplegia in the moderate LBCA group $(0 \%$ in deep LBCA group and $18 \%$ in moderate LBCA group, $P=$ .08). There were no significant differences in any other postoperative complications (Table 3).

\section{Subanalysis 2: Acute Aortic Dissection Type A}

Emergency operation for acute aortic dissection type A was a strong risk factor for mortality. In the entire study cohort, the mortalities were $5.6 \%$ among patients with nonacute dissection and $15.9 \%$ among those with acute dissection $(P=.001)$. To examine the effects of the temperature at LBCA on outcomes in this high-risk cohort, a subanalysis was performed on the entire patient population. There were no differences in perfusion data (CPB, aortic crossclamping, HCA, and SCP times). Mortalities were $18 \%$ (9/50 patients) in the deep LBCA group and $14.5 \%$ (11/76 patients) in the moderate LBCA group $(P=.59)$. There were no significant differences in rates of any postoperative complications between the groups (Table 4).

TABLE 3. Subanalysis: Patients with hypothermic circulatory arrest longer than 60 minutes

\begin{tabular}{|c|c|c|c|c|}
\hline & Overall & Deep LBCA & Moderate LBCA & $P$ value \\
\hline Patients (No.) & 27 & 16 & 11 & \\
\hline Age $(y$, mean $\pm S D)$ & $56.5 \pm 12.2$ & $53.7 \pm 12.3$ & $60.6 \pm 11.4$ & .15 \\
\hline Male (No.) & $22(81.5 \%)$ & $12(75.0 \%)$ & $10(90.9 \%)$ & .29 \\
\hline Type A dissection (No.) & $12(44.4 \%)$ & $4(25.0 \%)$ & $8(72.7 \%)$ & .014 \\
\hline Aortic valve root operation (No.) & $10(37.0 \%)$ & $4(25.0 \%)$ & $6(54.5 \%)$ & .12 \\
\hline Coronary artery bypass grafting (No.) & $4(14.8 \%)$ & $2(12.5 \%)$ & $2(18.2 \%)$ & .68 \\
\hline Total arch replacement (No.) & $23(85.2 \%)$ & $12(75.0 \%)$ & $11(100 \%)$ & .07 \\
\hline Duration of operation (min, mean $\pm S D$ ) & $364.7 \pm 136.1$ & $390.8 \pm 166.2$ & $326.8 \pm 63.6$ & .26 \\
\hline Duration of cardiopulmonary bypass (min, mean \pm SD) & $243.9 \pm 94.2$ & $266.6 \pm 112.2$ & $210.8 \pm 46.5$ & .13 \\
\hline Duration of aortic crossclamping (min, mean $\pm S D$ ) & $132.5 \pm 60.5$ & $127.2 \pm 68.7$ & $140.2 \pm 48.3$ & .59 \\
\hline Duration of hypothermic circulatory arrest (min, mean \pm SD) & $80.6 \pm 20.2$ & $85.3 \pm 22.5$ & $73.8 \pm 14.7$ & .15 \\
\hline Duration of selective cerebral perfusion (min, mean \pm SD) & $63.1 \pm 13.2$ & $61.8 \pm 11.9$ & $64.9 \pm 15.2$ & .56 \\
\hline Reexploration for bleeding (No.) & $9(33.3 \%)$ & $7(43.8 \%)$ & $2(18.2 \%)$ & .16 \\
\hline Duration of mechanical ventilation ( $h$, mean $\pm S D$ ) & $184.0 \pm 270.4$ & $155.1 \pm 223.4$ & $226.2 \pm 334.6$ & .51 \\
\hline Intensive care unit stay $(d$, mean $\pm S D)$ & $9.2 \pm 11.5$ & $7.8 \pm 9.0$ & $11.2 \pm 14.6$ & .44 \\
\hline In-hospital death (No.) & $5(18.5 \%)$ & $2(12.5 \%)$ & $3(27.3 \%)$ & .33 \\
\hline Stroke (No.) & $6(22.2 \%)$ & $3(18.8 \%)$ & $3(27.3 \%)$ & .60 \\
\hline Temporary neurologic dysfunction (No.) & $6(22.2 \%)$ & $5(31.3 \%)$ & $1(9.1 \%)$ & .17 \\
\hline Respiratory insufficiency (No.) & $6(22.2 \%)$ & $4(25.0 \%)$ & $2(18.2 \%)$ & .68 \\
\hline Postoperative use of dialysis (No.) & $4(14.8 \%)$ & $2(12.5 \%)$ & $2(18.2 \%)$ & .68 \\
\hline Paraplegia (No.) & $2(7.4 \%)$ & $0(0 \%)$ & $2(18.2 \%)$ & .08 \\
\hline
\end{tabular}

$\angle C B A$, Lower body circulatory arrest. 
TABLE 4. Subanalysis: Patients with acute aortic dissection type A

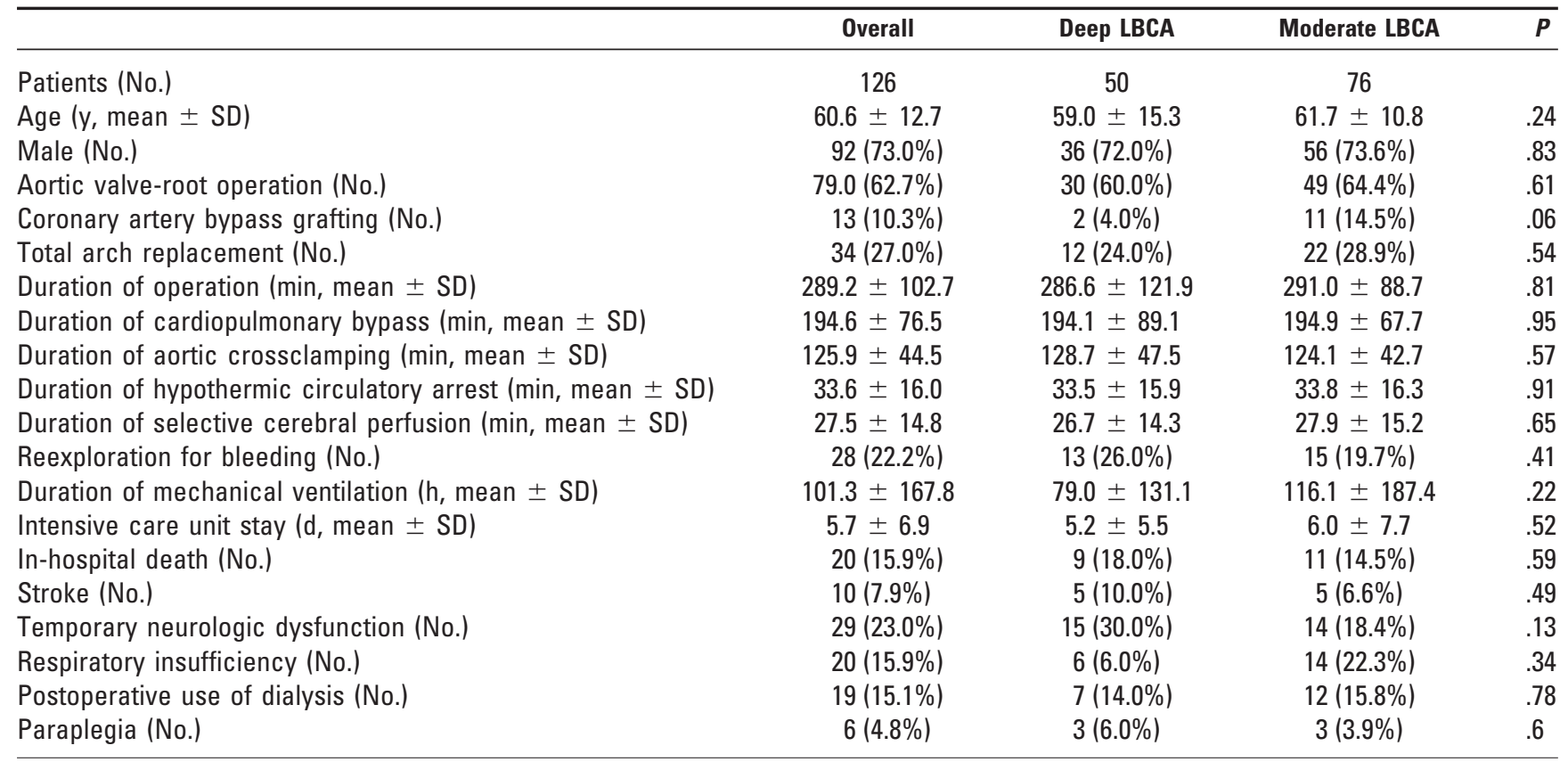

LCBA, Lower body circulatory arrest.

\section{Risk Factors for Postoperative Mortality and Morbidity}

To detect risk factors for postoperative mortality and morbidity in our study cohort, multivariate analyses were performed (Table 5). In these analyses, CPB and LBCA times were treated as a continuous variable, and the odds ratio reflected per degree risk. The temperature was also treated as a continuous variable, and the odds ratio therefore reflected per degree risk. Prolonged CPB was strongly associated with most postoperative adverse events, and the tem-

TABLE 5. Risk factors for postoperative mortality and morbidity analyzed with multivariate logistic regression

\begin{tabular}{|c|c|c|}
\hline & Entire study sample & Propensity-matched sample \\
\hline Mortality & CPB time $(P=.0001)$, OR $1.011,95 \% \mathrm{Cl} 1.007-1.016$ & $\begin{array}{l}\text { CPB time }(P=.001), \text { OR } 1.01195 \% \mathrm{Cl} 1.004-1.018 \\
\text { Reoperative case }(P=.014), 0 \mathrm{R} 6.66695 \% \mathrm{Cl} \\
\quad 1.457-30.439\end{array}$ \\
\hline $\begin{array}{l}\text { Temporary neurologic } \\
\text { dysfunction }\end{array}$ & $\begin{array}{l}\text { Age }(P=.003), \text { OR } 1.046,95 \% \mathrm{Cl} 1.016-1.077 \\
\text { Total arch replacement }(P=.008), 0 \mathrm{R} 3.83495 \% \\
\quad \mathrm{Cl} 1.422-10.339 \\
\text { LBCA time }(P=.005), 0 \mathrm{R} 1.02995 \% \mathrm{Cl} 1.009-1.049\end{array}$ & None \\
\hline Stroke & $\begin{array}{l}\text { CPB time }(P=.006), \text { OR } 1.006,95 \% \mathrm{Cl} 1.002-1.013 \\
\text { LBCA time }(P=.008), \text { OR } 1.030,95 \% \mathrm{Cl} 1.008-1.053\end{array}$ & $\begin{array}{l}\text { CPB time }(P=.006), \text { OR } 1.01195 \% \mathrm{Cl} 1.003-1.019 \\
\text { LBCA time }(P=.028), \text { OR } 1.05695 \% \mathrm{Cl} 1.006-1.109\end{array}$ \\
\hline Reexploration for bleeding & CPB time $(P=.002)$, OR $1.006,95 \% \mathrm{Cl} 1.002-1.010$ & $\begin{array}{l}\text { CPB time }(P=.004), 0 \mathrm{R} 1.00995 \% \mathrm{Cl} 1.003-1.015 \\
\text { Reoperative case }(P=.014), 0 \mathrm{R} 3.90295 \% \mathrm{Cl} \\
\quad 1.324-11.497 \\
\text { Temperature }(P=.046), 0 \mathrm{R} 0.79695 \% \mathrm{Cl} 0.636- \\
\quad 0.996\end{array}$ \\
\hline Respiratory failure & $\begin{array}{l}\text { Reoperative case }(P=.005), \text { OR } 3.63795 \% \mathrm{Cl} \\
\quad 1.484-8.910 \\
\text { CPB time }(P=.002), 0 \mathrm{R} 1.00795 \% \mathrm{Cl} 1.002-1.011 \\
\text { Age }(P=.002), 0 \mathrm{R} 1.06395 \% \mathrm{Cl} 1.024-1.104\end{array}$ & $\begin{array}{l}\text { Reoperative case }(P=.037), 0 \mathrm{R} 3.89695 \% \mathrm{Cl} \\
\quad 1.086-13.977 \\
\text { CPB time }(P=.0001), \text { OR } 1.01195 \% \mathrm{Cl} 1.005-1.017\end{array}$ \\
\hline Postoperative dialysis & $\begin{array}{l}\text { Age }(P=.002), \text { OR } 1.07495 \% \mathrm{Cl} 1.027-1.124 \\
\text { CPB time }(P=.005), \text { OR } 1.00795 \% \mathrm{Cl} 1.002-1.012\end{array}$ & $\begin{array}{l}\text { Age }(P=.024), \text { OR } 1.08995 \% \mathrm{Cl} 1.011-1.174 \\
\text { CPB time }(P=.004), \text { OR } 1.01295 \% \mathrm{Cl} 1.004-1.021)\end{array}$ \\
\hline Paraplegia & None & $\mathrm{BMI}(P=.019)$, OR $1.31595 \% \mathrm{Cl} 1.045-1.654$ \\
\hline
\end{tabular}

$C P B$, Cardiopulmonary bypass; $O R$, odds ratio; $C l$, confidence interval; $L B C A$, lower body circulatory arrest; $B M I$, body mass index. 
TABLE 6. Association between postoperative complications and temperature

\begin{tabular}{|c|c|c|c|c|c|c|c|c|c|c|c|c|}
\hline \multirow[b]{2}{*}{ Variable } & \multicolumn{6}{|c|}{ Entire study sample } & \multicolumn{6}{|c|}{ Propensity-matched sample } \\
\hline & Status & $\begin{array}{c}\text { Mean } \\
\text { temp }\left({ }^{\circ} \mathrm{C}\right)\end{array}$ & $\begin{array}{c}\text { Uni } \\
P \\
\text { value }\end{array}$ & $\begin{array}{c}\text { Multi } \\
\qquad \\
\text { value }\end{array}$ & $\mathbf{O R}$ & $95 \% \mathrm{Cl}$ & Status & $\begin{array}{c}\text { Mean } \\
\text { temp }\left({ }^{\circ} \mathrm{C}\right)\end{array}$ & $\begin{array}{c}\text { Uni } \\
P \\
\text { value }\end{array}$ & $\begin{array}{c}\text { Multi } \\
P \\
\text { value }\end{array}$ & $\mathbf{O R}$ & $95 \% \mathrm{Cl}$ \\
\hline \multirow[t]{2}{*}{ Mortality } & Dead $(n=34)$ & $24.9 \pm 2.1$ & .13 & .91 & 0.98 & $0.752-1.292$ & Dead $(n=18)$ & $24.8 \pm 2.0$ & .94 & .587 & 1.090 & $0.799-1.485$ \\
\hline & $\begin{array}{l}\text { Survived } \\
\qquad(\mathrm{n}=343)\end{array}$ & $25.4 \pm 1.7$ & & & & & $\begin{array}{l}\text { Survived } \\
\qquad(\mathrm{n}=166)\end{array}$ & $24.9 \pm 1.9$ & & & & \\
\hline \multirow[t]{2}{*}{ TND } & Yes $(n=52)$ & $25.1 \pm 1.7$ & .24 & .76 & 0.97 & $0.179-1.184$ & Yes $(n=22)$ & $24.9 \pm 1.6$ & .66 & .441 & 1.108 & $0.854-0.147$ \\
\hline & No $(\mathrm{n}=325)$ & $25.4 \pm 1.8$ & & & & & No $(n=162)$ & $24.8 \pm 1.9$ & & & & \\
\hline \multirow[t]{2}{*}{ Stroke } & Yes $(n=23)$ & $24.9 \pm 2.1$ & .37 & .82 & 1.04 & $0.733-1.479$ & Yes $(n=12)$ & $24.7 \pm 2.2$ & .86 & .982 & 1.004 & $0.691-1.460$ \\
\hline & No $(n=354)$ & $25.3 \pm 1.8$ & & & & & No $(n=172)$ & $24.8 \pm 1.9$ & & & & \\
\hline \multirow{2}{*}{$\begin{array}{l}\text { Reexploration } \\
\text { for bleeding }\end{array}$} & Yes $(n=58)$ & $24.9 \pm 2.2$ & .05 & .39 & 0.92 & $0.754-1.117$ & Yes $(n=31)$ & $24.1 \pm 2.2$ & .03 & .046 & 0.796 & $0.636-0.996$ \\
\hline & No $(n=319)$ & $25.4 \pm 1.7$ & & & & & No $(n=153)$ & $24.9 \pm 1.8$ & & & & \\
\hline \multirow{2}{*}{$\begin{array}{l}\text { Respiratory } \\
\text { failure }\end{array}$} & Yes $(n=40)$ & $25.1 \pm 1.8$ & .40 & .45 & 1.10 & $0.852-1.430$ & Yes $(n=22)$ & $24.6 \pm 2.1$ & .59 & .839 & 1.029 & $0.779-1.360$ \\
\hline & No $(\mathrm{n}=337)$ & $25.3 \pm 1.8$ & & & & & No $(n=162)$ & $24.8 \pm 1.8$ & & & & \\
\hline \multirow{2}{*}{$\begin{array}{l}\text { Postoperative } \\
\text { dialysis }\end{array}$} & Yes $(n=28)$ & $24.8 \pm 1.8$ & .12 & .17 & 0.80 & $0.581-1.103$ & Yes $(n=14)$ & $24.3 \pm 1.7$ & .30 & .298 & 0.841 & $0.607-1.165$ \\
\hline & No $(\mathrm{n}=349)$ & $25.4 \pm 1.8$ & & & & & No $(n=170)$ & $24.8 \pm 1.9$ & & & & \\
\hline \multirow[t]{2}{*}{ Paraplegia } & Yes (n = 8) & $24.2 \pm 2.2$ & .08 & NA & NA & NA & Yes $(n=7)$ & $23.9 \pm 2.2$ & .20 & NA & NA & NA \\
\hline & No $(\mathrm{n}=369)$ & $25.3 \pm 1.8$ & & & & & No $(\mathrm{n}=177)$ & $24.8 \pm 2.2$ & & & & \\
\hline
\end{tabular}

temp, Temperature; Uni, univariate; Multi, multivariate; $O R$, Odds ratio; $C l$, confidence interval; $T N D$, temporary neurologic dysfunction; $N A$, not available.

perature was only statistically significantly associated with reexploration for bleeding. Paraplegia, an uncommon yet critical complication in arch replacement, was seen in 8 patients in our study cohort. In these analyses, no risk factors could be identified in the entire study cohort, and body mass index was the only risk factor for postoperative paraplegia in the propensity-matched cohort.

\section{Associations Between Postoperative Complications and Temperature}

To examine associations between postoperative complications and the temperature at the initiation of LBCA, univariate and multivariate analyses were performed ( $\mathrm{Ta}$ ble 6). In these analyses, the temperature was treated as a continuous variable and the odds ratio therefore reflected per degree risk. Reexploration for bleeding was the only factor significantly associated with temperature. In the entire study sample, the mean temperatures at the initiation of LBCA were $24.9^{\circ} \mathrm{C} \pm 2.2^{\circ} \mathrm{C}$ among patients who underwent reexploration and $25.4^{\circ} \mathrm{C} \pm 1.7^{\circ} \mathrm{C}$ among those without it $(P=.046)$, but this difference did not reach statistical significance in the multivariate analysis $(P=.39)$. In the propensity-matched cohort, the mean temperatures at the initiation of LBCA were $24.1^{\circ} \mathrm{C} \pm 2.2^{\circ} \mathrm{C}$ among patients who underwent reexploration and $24.9^{\circ} \mathrm{C} \pm 1.8^{\circ} \mathrm{C}$ among those without it $(P=.025)$; this difference also reached statistical significance in the multivariate analysis ( $P=.046$, odds ratio, 0.796). For the occurrence of paraplegia, multivariate analysis could not be performed because of the low number of events.

\section{Discussion}

In this study, there were no significant differences in mortality or morbidity between deep and moderate LBCA in either the entire study cohort or the propensity-matched cohort. There was a trend toward lower postoperative inflammatory response in patients with moderate LBCA, however, which fell short of reaching statistical significance, and deep LBCA was strongly associated with reexploration for bleeding.

At the beginning of this study, we found the differences in the distribution of patient baseline data to be too great for a proper analysis. Patients with deep LBCA had lower body mass index, greater incidence of Marfan syndrome, and more smoking history. Moreover, they underwent fewer concomitant procedures (Appendix Table E2), more total arch replacement, and longer duration of LBCA. To generate a reasonable control group, propensity matching was performed for this study. ${ }^{12,13}$ Because LBCA and aortic crossclamping times are dependent on the surgical procedure and independent of the temperature at the initiation of LBCA, both factors were included in the matching process. Operative and CPB times were not included in this process, because we considered those factors to be dependent on LBCA, aortic crossclamping, cooling, rewarming, and hemostasis times.

Against our speculation, there were no differences in CPB and operative times between the groups in the propensitymatched cohort. Generally, it is considered that deep hypothermia is associated with prolonged $\mathrm{CPB},{ }^{7}$ and Harrington and associates $^{14}$ reported that mean CPB times were $191 \pm 53$ 
minutes in a deep hypothermic CPB group and $131 \pm 48$ minutes in a moderate hypothermic CPB group $(P<.0001)$, with their deep hypothermic CPB group undergoing HCA for $31 \pm 14$ minutes. Theoretically, longer cooling and rewarming times are required for deep HCA; in our series, however, 75\% of patients underwent concomitant procedures during the cooling and rewarming phases. This may account for the lack of differences in CPB and operative times between the two groups.

As we speculated, there were no differences in neurologic adverse event between the groups in any analysis. SCP protocol was identical in the two groups, and hypothermia was only needed as a brain protection during the period from the termination of CPB to the initiation of SCP and from the termination of SCP to the resumption of CPB. In our series, the difference between HCA and SCP times was approximately 6 minutes. Our data suggest that the difference in temperature at LBCA does not affect the quality of cerebral protection during this period.

Although the spinal cord consists of neural cells such as are present in the cerebrum and is most likely sensitive to ischemic damage in a similar manner as in the brain, the occurrences of paraplegia were similar in the two groups. This outcome may have been due to our institutional perfusion protocol. We performed SCP with cold blood at $15^{\circ} \mathrm{C}$, and it was observed in general that the nasopharyngeal temperature would continue to fall during the LBCA period, commonly dropping to $20^{\circ} \mathrm{C}$, although the temperature of the bladder would remain at the temperature at the initiation of LBCA. The mechanism of this phenomenon is unclear, but perhaps it was caused by the collateral blood flow through the vertebral artery and the returned cool blood from the head to the right atrium. It can be speculated that this cooling phenomenon acted protectively for the spinal cord and therefore resulted in a relatively low incidence of paraplegia among patients with moderate LBCA.

There were also no differences in the biologic parameters of any other organs. Similar to our results, Harrington and associates ${ }^{14}$ concluded that hypothermic CPB is not a risk factor for renal or early pulmonary dysfunction. Generally, visceral organs, including the lungs, can tolerate ischemic damage better than can the brain or the heart. Our results suggest that visceral organs can be well protected by moderate LBCA.

In this series, only the difference in C-reactive protein level 1 day after the operation approached statistical significance $(P=.08)$. The actual adverse effects of deep hypothermia on inflammatory response have not been made clear, but our results suggest that deep LBCA may activate inflammatory response, as others have already speculated. ${ }^{7,15}$ This issue, however, appears to be difficult to prove in a clinical setting. In this series there were no differences in any clinical outcomes except reexploration for bleeding.

It is well known that coagulopathy is induced by hypothermia ${ }^{16,17}$ but it has been difficult to prove this association in a clinical setting, especially with regard to HCA, as seen in the report by Harrington and associates ${ }^{14}$ in which profound hypothermia was not associated with increased postoperative hemorrhage in their comparative study of deep HCA. ${ }^{14}$ In our study, reexploration for bleeding was the only factor significantly associated with temperature. This result suggests that the use of deep LBCA can possibly cause postoperative bleeding.

Generally, acute aortic dissection type A is associated with high mortality, and this was also the case in our series. Even in this high-risk cohort, however, there were no differences in clinical outcome between the two groups. Our results demonstrate that moderate LBCA is a safe strategy for the treatment of acute aortic dissection type A.

Among the patients who underwent HCA for longer than 60 minutes, 2 patients ( 1 with acute aortic dissection type A and 1 without it) who underwent moderate LBCA had paraplegia occur, whereas none of those who underwent deep LBCA did $(P=.08)$. There were neither significant differences nor any trends toward significance in any other postoperative adverse effects. In our entire study cohort, only $7 \%$ of the patients $(n=27)$ underwent LBCA for longer than 60 minutes, as shown in Figure 1, and this patient volume was too small to conclude anything from a subanalysis. On the other hand, LBCA time was $50.2 \pm$ 20.7 minutes among patients who underwent total arch replacement and $20.4 \pm 13.1$ minutes among patients who underwent hemiarch replacement $(P=.0001)$, and the percentages of paraplegia were $4.7 \%$ (4/85 patients) and $1.4 \%$ (4/292 patients), respectively $(P=.064)$. In our institution, arch vessels are commonly reconstructed as an island, and this might explain why most of the cases were completed with less than 60 minutes of LBCA. Here it should be strongly emphasized that the results of this study do not support the suggestion that moderate LBCA has no time limit, and this method should not be used for patients who require complex total arch replacement with individual arch vessel reconstruction.

Unfortunately, we could not find the optimal temperature for LBCA and consider this a study limitation. The LBCA temperature ranged mainly from $25^{\circ} \mathrm{C}$ to $28^{\circ} \mathrm{C}$, and the optimal temperature could not be identified with this concentration in distribution in our preliminary pilot study. The temperature of $25^{\circ} \mathrm{C}$ to $28^{\circ} \mathrm{C}$ is quite higher than reported in other institutions, ${ }^{8-10}$ however, and we believe that it is meaningful to analyze and discuss the safety of LBCA in this temperature range.

In conclusion, there were no significant differences in mortality or morbidity between deep and moderate LBCA 
in either the entire study cohort or the propensity-matched cohort. There was a trend toward lower postoperative inflammatory response in patients with moderate LBCA, however, and deep LBCA was strongly associated with reexploration for bleeding. Our results suggest that moderate LBCA can be safely performed for aortic arch repair for 60 minutes or less. It remains unclear whether it is safe beyond 60 minutes.

\section{References}

1. Svensson LG, Crawford ES, Hess KR, Coselli JS, Raskin S, Shenaq $\mathrm{SA}$, et al. Deep hypothermia with circulatory arrest. Determinants of stroke and early mortality in 656 patients. J Thorac Cardiovasc Surg. 1993;106:19-28.

2. Griepp RB, Ergin MA, McCullough JN, Nguyen KH, Juvonen T, Chang $\mathrm{N}$, et al. Use of hypothermic circulatory arrest for cerebral protection during aortic surgery. J Card Surg. 1997;12(2 Suppl):312-21.

3. Mezrow CK, Midulla PS, Sadeghi AM, Gandsas A, Wang W, Dapunt $\mathrm{OE}$, et al. Evaluation of cerebral metabolism and quantitative electroencephalography after hypothermic circulatory arrest and low-flow cardiopulmonary bypass at different temperatures. $J$ Thorac Cardiovasc Surg. 1994;107:1006-19.

4. McCullough JN, Zhang N, Reich DL, Juvonen TS, Klein JJ, Spielvogel $\mathrm{D}$, et al. Cerebral metabolic suppression during hypothermic circulatory arrest in humans. Ann Thorac Surg. 1999;67:1895-9.

5. Ergin MA, Galla JD, Lansman SL, Quintana C, Bodian C, Griepp RB, Hypothermic circulatory arrest in operations on the thoracic aorta. Determinants of operative mortality and neurologic outcome. J Thorac Cardiovasc Surg. 1994;107:788-99.

6. Hagl C, Ergin MA, Galla JD, Lansman SL, McCullough JN, Spielvogel $\mathrm{D}$, et al. Neurologic outcome after ascending aorta-aortic arch operations: effect of brain protection technique in high-risk patients. $J$ Thorac Cardiovasc Surg. 2001;121:1107-21.
7. Hagl C, Khaladj N, Karck M, Kallenbach K, Leyh R, Winterhalter M, et al. Hypothermic circulatory arrest during ascending and aortic arch surgery: the theoretical impact of different cerebral perfusion techniques and other methods of cerebral protection. Eur J Cardiothorac Surg. 2003;24:371-8.

8. Bachet J, Guilmet D, Goudot B, Dreyfus GD, Delentdecker P, Brodaty D, et al. Antegrade cerebral perfusion with cold blood: a 13-year experience. Ann Thorac Surg. 1999;67:1874-8.

9. Kazui T, Kimura N, Komatsu S. Surgical treatment of aortic arch aneurysms using selective cerebral perfusion. Experience with 100 patients. Eur J Cardiothorac Surg. 1995;9:491-5.

10. Di Eusanio M, Schepens MA, Morshuis WJ, Di Bartolomeo R, Pierangeli A, Dossche KM. Antegrade selective cerebral perfusion during operations on the thoracic aorta: factors influencing survival and neurologic outcome in 413 patients. J Thorac Cardiovasc Surg. 2002;124:1080-6.

11. Minatoya K, Karck M, Szpakowski E, Harringer W, Haverich A Ascending aortic cannulation for Stanford type A acute aortic dissection: another option. J Thorac Cardiovasc Surg. 2003;125:952-3.

12. Blackstone EH. Comparing apples and oranges. J Thorac Cardiovasc Surg. 2002;123:8-15.

13. Kunihara T, Grun T, Aicher D, Langer F, Adam O, Wendler O, et al. Hypothermic circulatory arrest is not a risk factor for neurologic morbidity in aortic surgery: a propensity score analysis. $J$ Thorac Cardiovasc Surg. 2005;130:712-8.

14. Harrington DK, Lilley JP, Rooney SJ, Bonser RS. Nonneurologic morbidity and profound hypothermia in aortic surgery. Ann Thorac Surg. 2004;78:596-601.

15. Takano H, Sakakibara T, Matsuwaka R, Hori T, Sakagoshi N, Shinohara $\mathrm{N}$. The safety and usefulness of cool head-warm body perfusion in aortic surgery. Eur J Cardiothorac Surg. 2000;18:262-9.

16. Reed RL 2nd, Bracey AW Jr, Hudson JD, Miller TA, Fischer RP. Hypothermia and blood coagulation: dissociation between enzyme activity and clotting factor levels. Circ Shock. 1990;32:141-52.

17. Mora Mangano CT, Neville MJ, Hsu PH, Mignea I, King J, Miller DC. Aprotinin, blood loss, and renal dysfunction in deep hypothermic circulatory arrest. Circulation. 2001;104(12 Suppl 1):I276-81 . 


\section{Appendix TABLE E1.}

Perioperative parameters from propensity-matched cohort

\begin{tabular}{|c|c|c|c|}
\hline & Deep LBCA & Moderate LBCA & $P$ value \\
\hline Preoperative & $6.7 \pm 2.8$ & $6.9 \pm 3.7$ & .79 \\
\hline $6 \mathrm{~h}$ after operation & $7.5 \pm 3.1$ & $7.3 \pm 2.9$ & .77 \\
\hline $1 \mathrm{~d}$ after operation & $9.2 \pm 3.9$ & $8.9 \pm 4.1$ & 69 \\
\hline $5 \mathrm{~d}$ after operation & $9.7 \pm 6.1$ & $10.4 \pm 7.3$ & .55 \\
\hline $0 \mathrm{~h}$ after operation & $91.0 \pm 49.2$ & $89.9 \pm 27.4$ & .85 \\
\hline $6 \mathrm{~h}$ after operation & $103.3 \pm 53.5$ & $98.7 \pm 40.3$ & .52 \\
\hline $1 \mathrm{~d}$ after operation & $119.7 \pm 78.6$ & $117.5 \pm 74.8$ & .84 \\
\hline $5 \mathrm{~d}$ after operation & $103.5 \pm 72.2$ & $105.8 \pm 81.0$ & .85 \\
\hline \multicolumn{4}{|l|}{ Aspartate aminotransferase (U/L) } \\
\hline $5 \mathrm{~d}$ after operation & $91.0 \pm 49.2$ & $91.0 \pm 49.2$ & .50 \\
\hline \multicolumn{4}{|l|}{ Creatine kinase (U/L) } \\
\hline Preoperative & $66.6 \pm 61.8$ & $101.0 \pm 293.8$ & .30 \\
\hline $0 \mathrm{~h}$ after operation & $338.6 \pm 376.7$ & $302.4 \pm 301.1$ & .48 \\
\hline $6 \mathrm{~h}$ after operation & $538.2 \pm 643.8$ & $735.3 \pm 2062.2$ & .39 \\
\hline $1 \mathrm{~d}$ after operation & $771.2 \pm 1087.2$ & $1215.2 \pm 3567.1$ & .26 \\
\hline $5 \mathrm{~d}$ after operation & $284.8 \pm 840.9$ & $280.2 \pm 708.7$ & .97 \\
\hline \multicolumn{4}{|l|}{ Lactate $(\mathrm{mmol} / \mathrm{L})$} \\
\hline Preoperative & $2.8 \pm 1.2$ & $2.3 \pm 1.7$ & .60 \\
\hline $0 \mathrm{~h}$ after operation & $6.4 \pm 4.1$ & $5.9 \pm 3.0$ & .63 \\
\hline $6 \mathrm{~h}$ after operation & $5.5 \pm 3.6$ & $5.5 \pm 3.8$ & .97 \\
\hline \multicolumn{4}{|l|}{ C-reactive protein (mg/L) } \\
\hline $5 \mathrm{~d}$ after operation & $134.2 \pm 71.1$ & $123.8 \pm 47.6$ & .31 \\
\hline \multicolumn{4}{|c|}{ Arterial oxygen fraction/inspired oxygen fraction } \\
\hline Preoperative & $377.9 \pm 110.7$ & $369.9 \pm 116.1$ & .65 \\
\hline $0 \mathrm{~h}$ after operation & $345.3 \pm 125.7$ & $335.9 \pm 131.3$ & .64 \\
\hline $6 \mathrm{~h}$ after operation & $325.8 \pm 123.9$ & $321.6 \pm 105.6$ & .81 \\
\hline Urinary output first 24 h (mL) & $2556.1 \pm 1016.3$ & $2694.2 \pm 1351.7$ & .44 \\
\hline
\end{tabular}

All data are mean $\pm \mathrm{SD}$. $L C B A$, Lower body circulatory arrest. 


\section{Appendix TABLE E2.}

Concomitant operations

\begin{tabular}{|c|c|c|c|c|c|c|c|c|}
\hline & \multicolumn{4}{|c|}{ Entire study sample } & \multicolumn{4}{|c|}{ Propensity-matched pairs } \\
\hline & Overall & $\begin{array}{l}\text { Deep } \\
\text { LBCA }\end{array}$ & $\begin{array}{l}\text { Moderate } \\
\text { LBCA }\end{array}$ & $P$ value & Overall & $\begin{array}{l}\text { Deep } \\
\text { LBCA }\end{array}$ & $\begin{array}{l}\text { Moderate } \\
\text { LBCA }\end{array}$ & $P$ value \\
\hline Concomitant operation & $280(74.3 \%)$ & $85(68.0 \%)$ & $195(77.3 \%)$ & .05 & $138(75.0 \%)$ & $69(75.0 \%)$ & $69(75.0 \%)$ & $>.99$ \\
\hline Aortic valve root operation & $252(66.8 \%)$ & $76(60.8 \%)$ & $176(69.8 \%)$ & .79 & $122(66.3 \%)$ & $61(66.3 \%)$ & $61(66.3 \%)$ & $>.99$ \\
\hline Coronary artery bypass grafting & $80(21.2 \%)$ & $19(15.2 \%)$ & $61(24.2 \%)$ & .44 & $32(17.4 \%)$ & $14(15.2 \%)$ & $18(19.5 \%)$ & .43 \\
\hline Mitral valve operation & $6(1.6 \%)$ & $0(0 \%)$ & $6(2.3 \%)$ & .82 & $0(0 \%)$ & $0(0 \%)$ & $0(0 \%)$ & \\
\hline
\end{tabular}

All data are numbers and percentages of patients. $L C B A$, Lower body circulatory arrest. 